\title{
Effect of Concentration of Sodium Hydroxide and Degree of Heat Curing on Fly Ash-Based Geopolymer Mortar
}

\author{
Subhash V. Patankar, ${ }^{1}$ Yuwaraj M. Ghugal, ${ }^{2}$ and Sanjay S. Jamkar1 \\ ${ }^{1}$ Department of Applied Mechanics, Government College of Engineering, Aurangabad, Maharashtra 431005, India \\ ${ }^{2}$ Department of Applied Mechanics, Government College of Engineering, Karad, Maharashtra 431416, India \\ Correspondence should be addressed to Subhash V. Patankar; svpatankar11@rediffmail.com
}

Received 22 January 2014; Revised 1 April 2014; Accepted 15 April 2014; Published 5 May 2014

Academic Editor: Marino Lavorgna

Copyright (c) 2014 Subhash V. Patankar et al. This is an open access article distributed under the Creative Commons Attribution License, which permits unrestricted use, distribution, and reproduction in any medium, provided the original work is properly cited.

\begin{abstract}
Geopolymer concrete/mortar is the new development in the field of building constructions in which cement is totally replaced by pozzolanic material like fly ash and activated by alkaline solution. This paper presented the effect of concentration of sodium hydroxide, temperature, and duration of oven heating on compressive strength of fly ash-based geopolymer mortar. Sodium silicate solution containing $\mathrm{Na}_{2} \mathrm{O}$ of $16.45 \%, \mathrm{SiO}_{2}$ of $34.35 \%$, and $\mathrm{H}_{2} \mathrm{O}$ of $49.20 \%$ and sodium hydroxide solution of $2.91,5.60,8.10,11.01$, 13.11, and 15.08. Moles concentrations were used as alkaline activators. Geopolymer mortar mixes were prepared by considering solution-to-fly ash ratio of $0.35,0.40$, and 0.45 . The temperature of oven curing was maintained at $40,60,90$, and $120^{\circ} \mathrm{C}$ each for a heating period of 24 hours and tested for compressive strength at the age of 3 days as test period after specified degree of heating. Test results show that the workability and compressive strength both increase with increase in concentration of sodium hydroxide solution for all solution-to-fly ash ratios. Degree of heating also plays vital role in accelerating the strength; however there is no large change in compressive strength beyond test period of three days after specified period of oven heating.
\end{abstract}

\section{Introduction}

Cement industry is one of the major contributors to the emission of green house gasses like carbon dioxide which is about 1.35 billion tons annually $[1,2]$. Day by day the World's Portland cement production increases with the increasing demand of construction industry which crossed one thousand million tons per year. On the other side, fly ash is the waste material of coal based thermal power plant, which is available abundantly but creates disposal problem. Several hectors of valuable land is required for their disposal. As fly ash is light in weight and easily flies, this creates severe health problems like asthma, bronchitis, and so forth. According to the survey, the total fly ash production in the world is about 780 million tons per year [3]. With silicon and aluminum as the main constituents, fly ash is an effective cement replacing material but the utilization is only $17-25 \%$. At present, fly ash is used in the production of Portland Pozzolana Cement, partial replacement of cement and workability improving admixture in concrete, and also in the production of cellular blocks and bricks and in soil stabilization [4]. For every ton of fly ash used in place of Portland cement saves about a ton of carbon dioxide emission to the atmosphere [3]. The mortar and concrete made with fly ash are eco-friendly and can be made to replace more than $50 \%$ of the cement to produce high volume fly ash concrete [5].

But for full utilization of fly ash, Davidovits $[1,6,7]$ suggested the activation process in which cement is totally replaced by pozzolanic material and activated by alkaline solution known as geopolymer. The development of geopolymer concrete/mortar can provide a solution to produce greener construction materials for sustainable development.

Davidovits $[1,6,8]$ highlighted the global warming impact due to $\mathrm{CO}_{2}$ emission from Portland cement productions and the need of low $\mathrm{CO}_{2}$ emissions cementitious materials. Rai et al. [9] presented several environmental aspects of coal ash disposal and ground water contamination, while Pandey et al. [10] highlighted the problem due to generation of fly ash in thermal power plants and its disposal, along with the pollution involved due to presence of arsenic. Rajamane 
TABle 1: Chemical composition of fly ash.

\begin{tabular}{lccccccccc}
\hline Chemical composition & $\mathrm{SiO}_{2}$ & $\mathrm{Al}_{2} \mathrm{O}_{3}$ & $\mathrm{Fe}_{2} \mathrm{O}_{3}$ & $\mathrm{MgO}$ & $\mathrm{SO}_{3}$ & $\mathrm{Na}_{2} \mathrm{O}$ & $\mathrm{CaO}$ & Total chlorides & Loss of ignition \\
\hline Percentage & 77.10 & 17.71 & 01.21 & 0.90 & 2.20 & 0.80 & 0.62 & 0.03 & 0.87 \\
\hline
\end{tabular}

and Sabitha [11] studied the pozzolanic action of fly ash and silica fume with the calcium hydroxide generated during the hydration of cement. Suri [12] explained the application of fly ash for making innovative building products for construction from partial to full utilization of fly ash in geopolymer concrete. Jiminez et al. [13] reported that the activated fly ash has fast setting and rapid strength development properties and is also used for the immobilisation of toxic waste. Davidovits [14] demonstrated the polycondensation of geopolymer at temperatures lower than $100^{\circ} \mathrm{C}$ and the chemical reaction involved in their formation. Hardjito et al. [2,15] studied the effect of water-to-geopolymer solids ratio by mass on compressive strength of fly ash-based geopolymer concrete, while Fongjan and Ludger [16] observed the oxide-mole ratios, physical properties, and morphologies of solid materials and curing conditions are the key factors influencing the potential properties of geopolymeric mortar. Rangan et al. [17] found that the fly ash-based geopolymer concrete has excellent resistance to sulfate attack, undergoes low creep, and suffers very little drying shrinkage. Hardjito et al. [18] studied the effects of the mixing time and the rest period while Sumajouw et al. [19] studied the behavior and the strength of reinforced geopolymer concrete columns and beams. The effect of the molar composition of the oxides present in the mixture and the water content used on the polymerization process has been studied by Barbosa et al. [20]. van Jaarsveld et al. [21] observed that the water content has a substantial effect on the final properties of the geopolymer, while solution-to-fly ash ratio is not a relevant parameter as observed by Palomo and Fernandez-Jimenez [22]. Ranganath and Mohammed [23] highlighted the effect of fly ash, water content, sodium silicate-to-sodium hydroxide ratio, and the duration of elevated temperature curing on the properties of geopolymer concrete, whereas Mustafa Al Bakri et al. [24] and Jamkar et al. [25] observed the increase in workability and compressive strength with the increase in fineness of fly ash.

In the present investigation, an experimental work is carried out to study the effect of various concentrations of sodium hydroxide solution in terms of molarity at solutionto-fly ash ratios of $0.30,0.35$, and 0.40 on workability in terms of flow in plastic state and effect of degree of heating on compressive strength after specified period of heat curing of fly ash-based geopolymer mortar.

\section{Experimental Program}

2.1. Materials. In the present investigation, a low calcium processed fly ash was used as a source material. The residue of fly ash retained on $45 \mu \mathrm{m}$ IS sieve was reported as $7.67 \%$. Table 1 shows the chemical composition of dry processed fly ash sample. The laboratory grade sodium hydroxide in flake form ( $97.8 \%$ purity) and sodium silicate (50.72\% solids) solutions were used as alkaline activators. Locally available river sand was used as filler material. The sand is sieved using IS sieves of sizes $2 \mathrm{~mm}, 1 \mathrm{~mm}, 500$ micron, and 90 micron. These size fractions are combined in equal proportion to maintain grading complying with standard sand as per IS 650: 1991. The alkaline solution-to-fly ash ratios were considered as $0.35,0.40$, and 0.45 for each $2.91 \mathrm{M}, 5.61 \mathrm{M}, 8.11 \mathrm{M}$, 11.01 M, 13.11 M, and 15.06 M concentrated sodium hydroxide solutions. Oven curing was done at $60^{\circ} \mathrm{C}, 90^{\circ} \mathrm{C}$, and $120^{\circ} \mathrm{C}$ each for a heating period of 24 hours duration and tested after 3 days of test period after heating.

\subsection{Preparation of Sodium Hydroxide Solution. Depending} on the concentration of sodium hydroxide solution required, flakes of sodium hydroxide were added in a liter of distilled water instead of preparing one-liter solution. Then molarity was found from the laboratory measurements. For example, $3 \mathrm{M}$ sodium hydroxide solution consists of $3 \times 40=120$ grams of $\mathrm{NaOH}$ solids per liter of solution. But instead of that, 120 gm sodium hydroxide flakes were added in a liter of distilled water. So the total volume of solution was 1.030 liter. The solid contained in a liter of sodium hydroxide solution was estimated as $(120 / 1030) \times 1000=116.40 \mathrm{gm}$. Therefore the molarity of solution is $(116.40 / 40)=2.91 \mathrm{M}$ instead of $3 \mathrm{M}$. Sodium hydroxide solution was prepared two days prior to the casting of mortar cubes so as to cool down the solution up to room temperature specifically in summer season.

2.3. Preparation of Geopolymer Mortar Mixes. Geopolymer mortar mixes were prepared after replacing cement totally by the same amount of fly ash and activating it by alkaline solutions of sodium hydroxide and sodium silicate. Geopolymer mortar cubes were prepared using $1: 3$ proportions of fly ash and locally available sand graded similar to standard sand. Quantities of alkaline solution and water were calculated by considering solution-to-fly ash ratio of $0.35,0.40$, and 0.45 , sodium silicate-to-sodium hydroxide ratio by mass of 1.0, and water-to-geopolymer solid ratio by mass of 0.2625 on the basis of past investigation [26]. Calculated quantities of sodium silicate solution mixed with sodium silicate solution along with extra water if any in a glass bottle of capacity five liter and agitated gently as to give homogeneous solution. Prepared solution was kept aside for about 2 hours as to avoid any contamination during casting.

Casting of geopolymer mortar is similar to that of cement mortar in which dry mixture of fly ash and graded sand was made in a bowl of capacity $6 \mathrm{~kg}$ and then alkaline solution is added to it and thoroughly mixed for 2 to 3 minutes so as to give homogeneous mix. It was found that the fresh fly ashbased geopolymer mortar was viscous, cohesive, and dark in colour. After making the homogeneous mix, workability of fresh geopolymer mortar was measured by flow table apparatus as per IS 5512-1983 and IS 1727-1967. Then for 


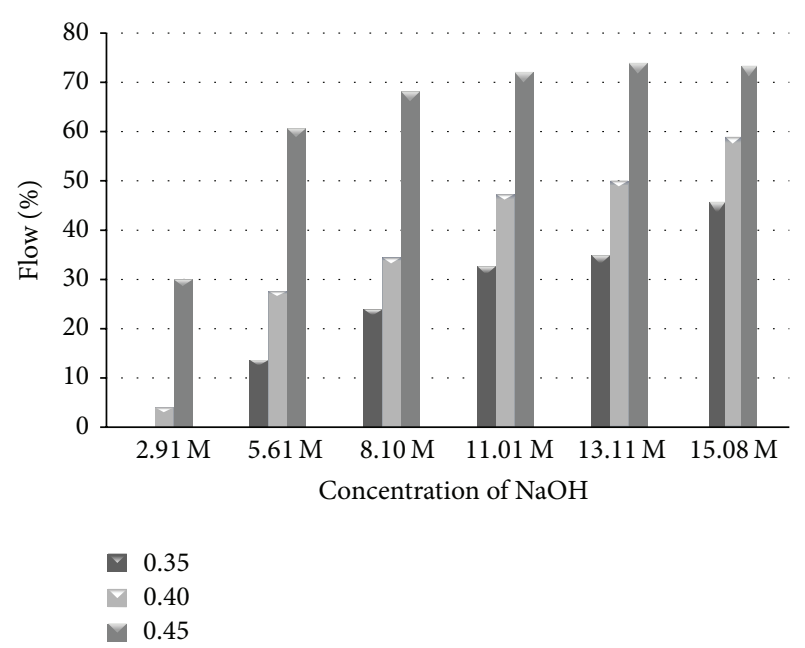

FIGURE 1: Effect of concentration of sodium hydroxide on flow of geopolymer mortar for different solution-to-fly ash ratios.

every concentration of sodium hydroxide, 48 cubes of size $70.7 \mathrm{~mm} \times 70.7 \mathrm{~mm} \times 70.7 \mathrm{~mm}$ were cast in three layers. Each layer was well compacted by tamping rod of diameter $20 \mathrm{~mm}$. After compaction of mortar, the top surface was leveled using trowel and the sides of mould were gently tapped to expel air, if any, present inside the mortar. All cubes were removed from moulds after 24 hours of casting and then placed in an oven for thermal curing (heating). To avoid the sudden variation in temperature, the mortar cubes were allowed to cool down up to room temperature in the oven itself. After 24 hours, specimens were removed from the oven and the weight of each specimen was taken for determination of mass density and then tested for compressive strength after 3 days of heating. Testing procedure is similar to that of cement mortar as mentioned in IS 4031(part-VI)-1981. Three cubes were cast and tested for compressive strength for each curing period.

\section{Result and Discussions}

Results of workability in terms of flow and effect of various concentrations of sodium hydroxide solution and temperature on compressive strength of geopolymer mortar are presented in the following sections.

\subsection{Effect of Concentration of Sodium Hydroxide on Workabil-} ity of Geopolymer Mortar. As geopolymer mortar was viscous and water comes out during polymerization process, the flow table test shows comparatively good results than the other methods of measurement of workability. Figure 1 shows the effect of concentration of sodium hydroxide solution in terms of molarity on flow of geopolymer mortar after 10 jolts for solution-to-fly ash ratios of $0.35,0.40$, and 0.45 . It is observed that the higher concentration of sodium hydroxide solution resulted in higher flow for alkaline solution-to-fly ash ratio of 0.35 and 0.40 . It means that the flow of geopolymer mortar increases with increase in concentration of sodium hydroxide

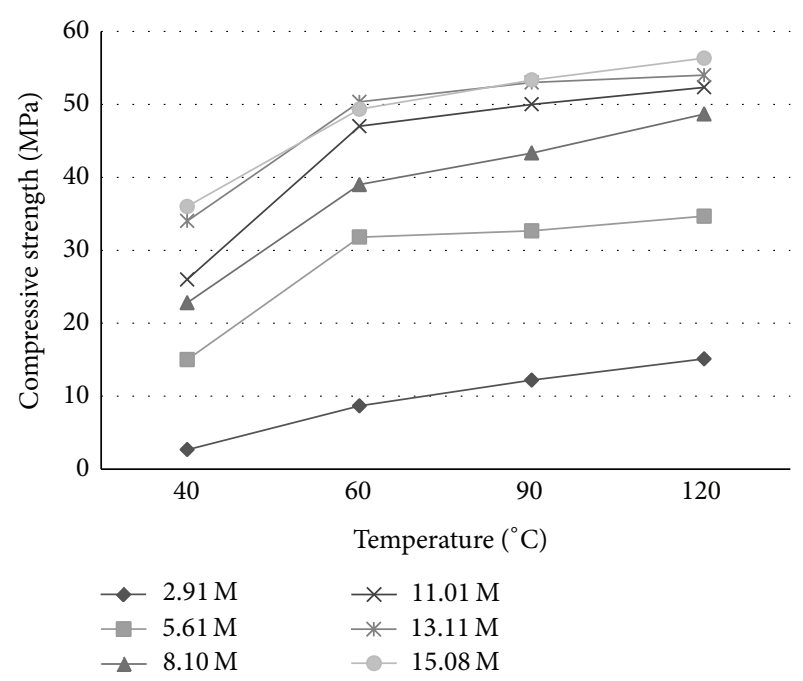

FIGURE 2: Effect of degree of heating for different concentrations of $\mathrm{NaOH}$ solution on compressive strength at solution-to-fly ash ratio of 0.35 .

solution. But for solution-to-fly ash ratio of 0.40 , the rate of gain of flow is not very significant at and above $11.01 \mathrm{M}$ concentration of sodium hydroxide solution. It might be due to reduction in quantity of water required to maintain the water-to-geopolymer solid ratio of 0.2625 in the mix and geopolymer mortar made with highly concentrated sodium hydroxide solution gives very viscous mix.

\subsection{Effect of Concentration of Sodium Hydroxide on Com-} pressive Strength of Geopolymer Mortar. Figure 2 shows the effect of concentration of sodium hydroxide solution in terms of molarity on compressive strength of geopolymer mortar heated in oven at temperatures $40,60,90$, and $120^{\circ} \mathrm{C}$ for duration of 24 hours and tested after 3 days of oven heating for solution-to-fly ash ratio of 0.35 . It is observed that the compressive strength of geopolymer concrete increases with increase in the concentration of sodium hydroxide solution for all temperatures but the rate of gain of strength is different for different concentrations of sodium hydroxide solution. The rate of gain of strength is higher in between curing temperatures of 40 and $60^{\circ} \mathrm{C}$ as compared to 60 to $90^{\circ} \mathrm{C}$ and 90 to $120^{\circ} \mathrm{C}$ for all concentrations of sodium hydroxide solution. However, there is no significant variation in compressive strength of geopolymer mortar at and above $13.11 \mathrm{M}$ concentration of sodium hydroxide solution. It is due to a very viscous mix formation at higher concentration of sodium hydroxide which creates compaction problem. It is also observed that the mild concentration of sodium hydroxide solution of $2.91 \mathrm{M}$ gives poor strength.

Figures 3 and 4 show the effect of concentration of sodium hydroxide solution on compressive strength of geopolymer mortar for solution-to-fly ash ratio of 0.40 and 0.45 by maintaining other parameters held constant. It is observed that the compressive strength of geopolymer concrete increases with increase in the concentration of sodium hydroxide solution for all temperatures but the rate of gain of strength 
TABLE 2: Effect of concentration of sodium hydroxide on dry mass density and alkalinity for solution-to-fly ash ratio of 0.35 .

\begin{tabular}{lcccccc}
\hline Mix number & 1 & 2 & 3 & 4 & 5 & 5 \\
\hline Concentration of $\mathrm{NaOH},(\mathrm{M})$ & 2.91 & 5.61 & 8.10 & 11.01 & 13.11 & 15.08 \\
\hline Mass density, $\left(\mathrm{kg} / \mathrm{m}^{3}\right)$ & 2180.85 & 2215.67 & 2157.65 & 2181.7 & 2168.97 \\
\hline Alkalinity, $\mathrm{pH}$ & 9.10 & 9.28 & 9.52 & 9.90 & 9.92 & 10.60 \\
\hline
\end{tabular}

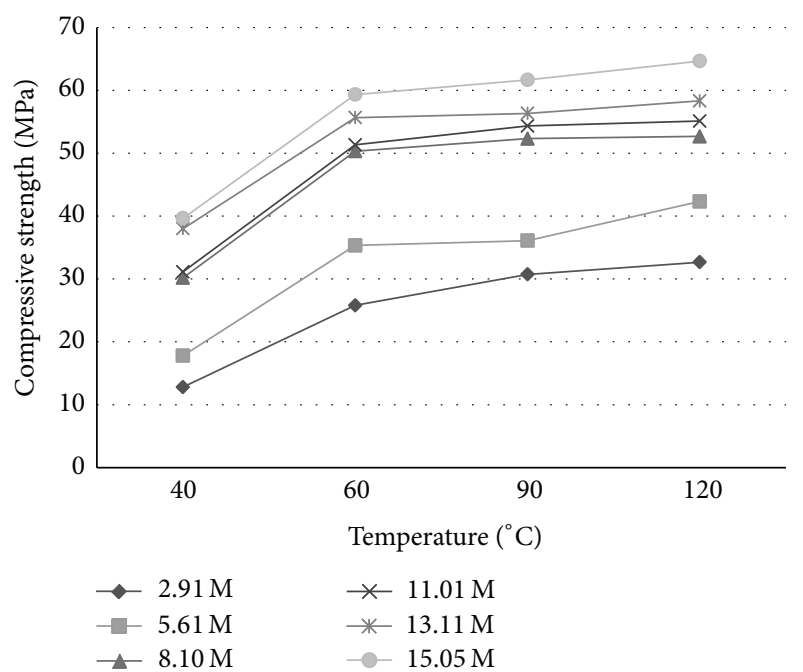

FigURE 3: Effect of degree of heating for different concentrations of $\mathrm{NaOH}$ solution on compressive strength at solution-to-fly ash ratio of 0.40 .

at and above $60^{\circ} \mathrm{C}$ is not very significant. That means the degree of heating at $60^{\circ} \mathrm{C}$ is sufficient when the solution-tofly ash ratios are 0.40 and 0.45 . Similarly sodium hydroxide solution with concentration of $8.01 \mathrm{M}$ is sufficient to achieve remarkable strength. Higher solution-to-fly ash ratio shows higher strength at the same concentration of sodium hydroxide solution. But higher solution-to-fly ash ratio gives more viscous mix and creates difficulties in compaction which ultimately reduce the strength as clearly observed from Figure 4 .

\subsection{Effect of Concentration of Sodium Hydroxide Solution} on Mass Density of Geopolymer Mortar. Table 2 shows the effect of concentration of sodium hydroxide solution on mass density of geopolymer mortar calculated after oven heating at $90^{\circ} \mathrm{C}$ for a duration of 24 hours and cooling the cubes in the oven for another 24 hours for solution-to-fly ash ratio of 0.35 . It is observed that the average mass density is $2178.73 \mathrm{~kg} / \mathrm{m}^{3}$ for all the mixes. There is no large variation in the mass density of geopolymer mortar for all concentrations of sodium hydroxide solution for all solution-to-fly ash ratios as observed from Tables 2, 3, and 4. That means the density of geopolymer concrete does not depend on concentration of sodium hydroxide solution as well as solution-to-fly ash ratios.

3.4. Effect of Concentration of Sodium Hydroxide Solution on Alkalinity of Geopolymer Mortar. After testing the mortar cubes for compressive strength, the mortar cube material

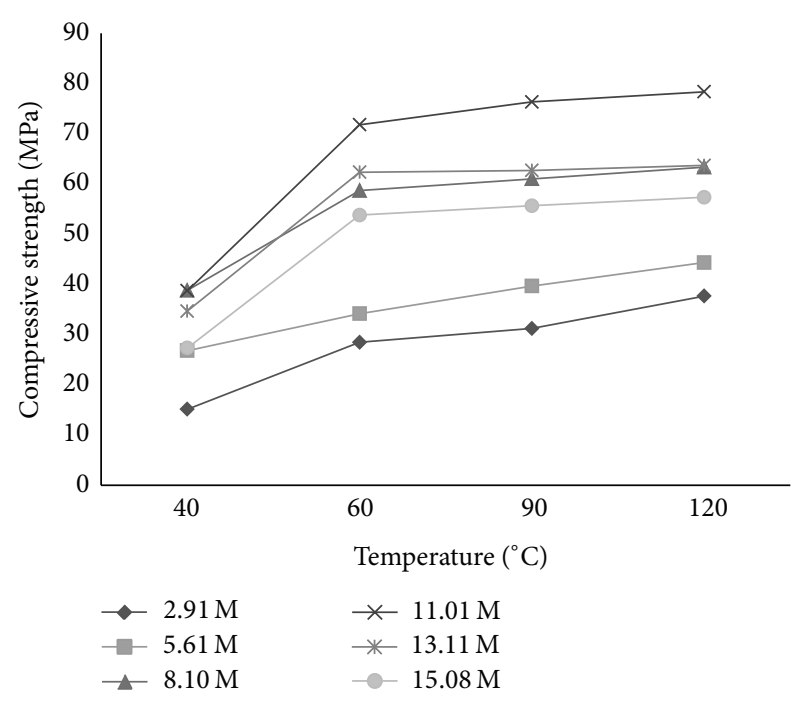

FIGURE 4: Effect of degree of heating for different concentrations of $\mathrm{NaOH}$ solution on compressive strength at solution-to-fly ash ratio of 0.45 .

was crushed and sieved through $90 \mu \mathrm{m}$ IS sieve. Then $20 \mathrm{gm}$ powdered material was taken with $200 \mathrm{~mL}$ distilled water in a glass beaker of capacity $500 \mathrm{~mL}$. The mixture was stirred for few minutes and after 24 hours the solution was filtered using Whatman paper No. 9. Then alkalinity of filtered solution was measured on digital $\mathrm{pH}$ meter.

Tables 2, 3, and 4 show the effect of concentration of sodium hydroxide solution on alkalinity of geopolymer mortar for solution-to-fly ash ratios of $0.35,0.40$, and 0.45 , respectively. It is observed that the alkalinity of geopolymer mortar is not much affected with increase in concentration of sodium hydroxide solution. The maximum $\mathrm{pH}$ value of geopolymer mortar is 10.92 which is less than that of conventional cement mortar $(\mathrm{pH}=11.3-11.6)$. That means that there is less chance of alkali-aggregate reaction even though highly alkaline solution is used for the preparation of geopolymer mortar.

3.5. Effect of Duration of Heating on Compressive Strength of Geopolymer Mortar. Figure 5 shows the effect of duration of heating on compressive strength of geopolymer mortar at $60^{\circ}$, $90^{\circ}$, and $120^{\circ} \mathrm{C}$ temperature for $13.11 \mathrm{M}$ concentrated sodium hydroxide solution at solution-to-fly ash ratio of 0.40 . It is observed that the compressive strength of geopolymer mortar increases with increase in duration of heating at a particular temperature. It is also observed that the rate of gain of strength increases as the duration of heating increases specifically at higher temperature. After 12 hours of temperature curing, the rate of gain of strength is not very significant 
TABLE 3: Effect of concentration of sodium hydroxide on dry mass density and alkalinity for solution-to-fly ash ratio of 0.40 .

\begin{tabular}{lcccccc}
\hline Mix number & 7 & 8 & 9 & 10 & 11 & 12 \\
\hline Concentration of $\mathrm{NaOH},(\mathrm{M})$ & 2.91 & 5.61 & 8.10 & 11.01 & 13.11 & 15.08 \\
\hline Mass density, $\left(\mathrm{Kg} / \mathrm{m}^{3}\right)$ & 2174.15 & 2298.39 & 2237.35 & 2201.51 & 2186.52 & 2189.35 \\
\hline Alkalinity, $\mathrm{pH}$ & 10.24 & 10.34 & 10.30 & 10.32 & 10.52 & 10.52 \\
\hline
\end{tabular}

TABLE 4: Effect of concentration of sodium hydroxide on dry mass density and alkalinity for solution-to-fly ash ratio of 0.45.

\begin{tabular}{lcccccc}
\hline Mix number & 13 & 14 & 15 & 16 & 17 & 18 \\
\hline Concentration of $\mathrm{NaOH},(\mathrm{M})$ & 2.91 & 5.61 & 8.10 & 11.01 & 13.11 & 15.08 \\
\hline Mass density, $\left(\mathrm{Kg} / \mathrm{m}^{3}\right)$ & 2169.91 & 2231.69 & 2130.3 & 2176.98 & 2182.84 & 2179.34 \\
\hline Alkalinity, $\mathrm{pH}$ & 10.52 & 10.50 & 10.30 & 10.71 & 10.80 & 10.92 \\
\hline
\end{tabular}

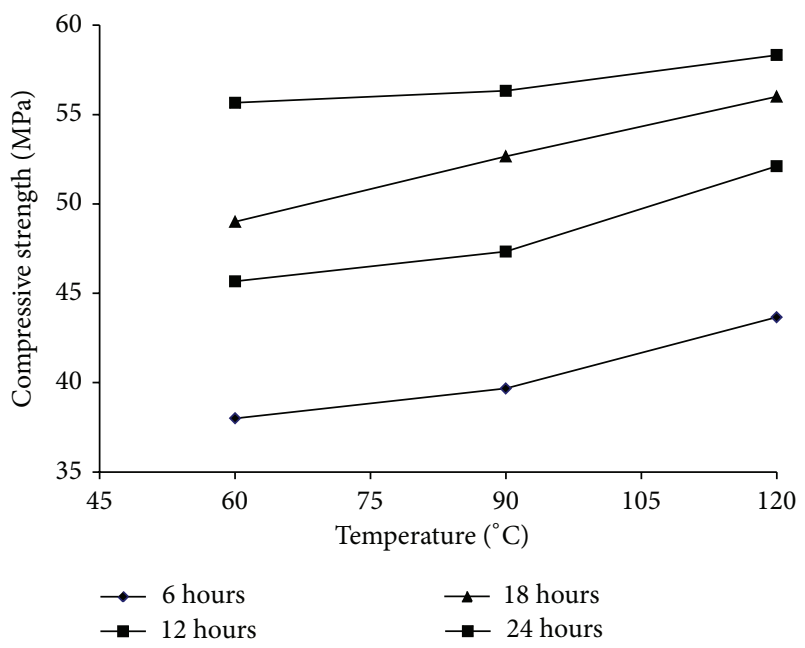

FIGURE 5: Effect of duration of heating on compressive strength at 13.11 $\mathrm{M} \mathrm{NaOH}$.

specifically at $90^{\circ} \mathrm{C}$ and $120^{\circ} \mathrm{C}$. But at heating temperature of $60^{\circ} \mathrm{C}$, the rate of gain of strength is constantly increasing for all curing periods. That means the strength of geopolymer concrete can be increased by increasing temperature with reduced duration of heating. But at heating temperature of $120^{\circ} \mathrm{C}$, cracks are developed on the concrete surface so the suitable temperature for making geopolymer concrete is in between 60 and $90^{\circ} \mathrm{C}$.

3.6. Effect of Test Period on Compressive Strength of Geopolymer Mortar. To optimize the duration of temperature curing, further investigation has been carried out by considering additional duration of 8 and 10 hours and for the test period of $1,2,3$, and 7 days by maintaining temperature curing at $90^{\circ} \mathrm{C}$. Figure 6 shows the effect of test period on compressive strength of geopolymer mortar at temperature curing of $90^{\circ} \mathrm{C}$ for various duration of heating. Test period is the duration of time considered after heating the cubes up to testing for compressive strength under ambient temperature. It is observed that the strength of geopolymer mortar increases with increase in test period when the duration of heating is 6 hours, while for higher duration of heating significant gain of strength is observed up to test period of 3 days and

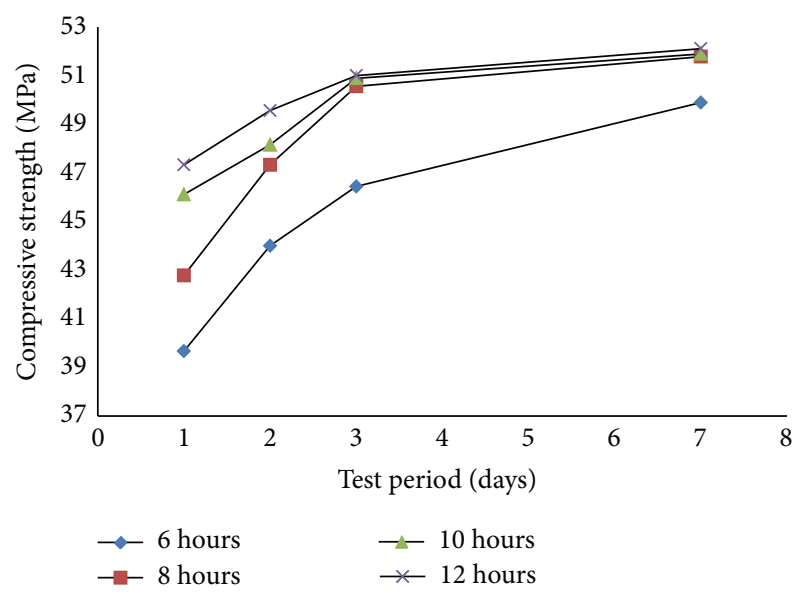

FIGURE 6: Effect of test period on compressive strength of geopolymer mortar at temperature curing of $90^{\circ} \mathrm{C}$ for various duration of heating.

then increases with slow rate. There is no large change in compressive strength of geopolymer mortar tested after test period of 3 days for 8,10 , and 12 hours of heating duration. That means only 3 days of test period is sufficient to achieve desired strength for oven heating at $90^{\circ} \mathrm{C}$ and for the duration of 8 hours.

\section{Conclusions}

This paper presented the effect of concentration of sodium hydroxide, temperature, duration of heating, and test period on the development of geopolymer mortar. It is observed that the workability as well as compressive strength of geopolymer mortar increases with increase in concentration of sodium hydroxide solution in terms of molarity. The rate of gain of strength is slow when heat cured at $40^{\circ} \mathrm{C}$ as compared to strength at $120^{\circ} \mathrm{C}$. But there is no appreciable change in compressive strength beyond curing temperature of $90^{\circ} \mathrm{C}$. Similarly, duration of heating in the range of 6 to 24 hours produces higher compressive strength. However, the increase in strength beyond 12 hours is not very significant. It is also observed that the compressive strength of geopolymer concrete increases with increase in test period up to three days. 
So, for the suitable preparation of geopolymer mortar, 13molar solution of sodium hydroxide is recommended on the basis of workability and compressive strength. Similarly it is also recommended that the cubes are cured in an oven at $90^{\circ} \mathrm{C}$ for 8 hours duration and tested after a test period of 3 days.

\section{Conflict of Interests}

The authors declare that there is no conflict of interests regarding the publication of this paper.

\section{References}

[1] J. Davidovits, "Global warming impact on the cement and aggregate industries," World Resource Review, vol. 6, no. 2, pp. 263-278, 1994.

[2] D. Hardjito, S. E. Wallah, D. M. J. Sumjouw, and B. V. Rangan, "Geopolymer concrete: turn waste into environmentally friendly concrete," in Proceedings of the International Conference on Recent Trends in Concrete Technology and Structures (INCONTEST '03), pp. 129-140, Coimbatore, India, 2003.

[3] D. Hardjito, S. E. Wallah, D. M. J. Sumjouw, and B. V. Rangan, "Properties of geopolymer concrete with fly ash as source material: effect of mixture composition," in Proceedings of the 7th CANMET/ACI International Conference on Recent Advances in Concrete Technology, pp. 26-29, Las Vegas, Nev, USA, 2004.

[4] V. Kumar, M. Mathur, S. S. Sinha, and S. Dhatrak, "Fly Ash: an environmental savior," in Fly Ash Utilisation Programme (FAUP), TIFAC, DST, pp. IV1.1-IV1.4, Fly Ash India, New Delhi, India, 2005.

[5] V. M. Malhotra and A. A. Ramezanianpour, Fly Ash in Concrete, Canada Centre for Mineral and Energy Technology (CANMET), 1994.

[6] J. Davidovits, "Geopolymers: man-made geosynthesis and the resulting development of very early high strength cement," Journal of Materials Education, vol. 16, no. 2-3, pp. 91-139, 1994.

[7] J. Davidovits, "Geopolymers-inorganic polymeric new materials," Journal of Thermal Analysis, vol. 37, no. 8, pp. 1633-1656, 1991.

[8] J. Davidovits, "Recent progresses in concretes for nuclear waste and uranium waste containment," Concrete International Journal, vol. 16, no. 12, pp. 53-58, 1994.

[9] A. K. Rai, B. Paul, and G. Singh, "A study on the environmental aspects of coal ash disposal," Indian Journal of Environmental Protection, vol. 30, no. 12, pp. 1025-1029, 2010.

[10] V. C. Pandey, J. S. Singh, R. P. Singh, N. Singh, and M. Yunus, "Arsenic hazards in coal fly ash and its fate in Indian scenario," Resources, Conservation and Recycling, vol. 55, no. 9-10, pp. 819835, 2011.

[11] N. P. Rajamane and D. Sabitha, "Effect of fly ash and silica fume on alkalinity of cement mortars," The Indian Concrete Journal, vol. 79, no. 3, pp. 43-48, 2005.

[12] S. B. Suri, "Fly ash based innovative building products for construction-part-II," CE \& CR, vol. 25, pp. 134-142, 2012.

[13] A. M. F. Jiminez, E. E. Lachowski, A. Palomo, and D. E. Macphee, "Microstructural characterisation of alkali-activated PFA matrices for waste immobilisation," Cement and Concrete Composites, vol. 26, no. 8, pp. 1001-1006, 2004.

[14] J. Davidovits, "Geopolymer chemistry and properties," in Proceedings of the 1st European Conference on Soft Mineralurgy (Geopolymere '88), pp. 25-48, Compiegne, France, 1988.
[15] D. Hardjito, S. E. Wallah, D. M. J. Sumjouw, and B. V. Rangan, "Brief review of geopolymer concrete," Invited Paper, George Hoff Symposium, American Concrete Institute, Los Vegas, Nev, USA, 2004.

[16] J. Fongjan and L. Ludger, "Effect of high silica content materials on fly ash-based geopolymeric cement materials," in Proceedings of the Geopolymer 2005 World Congress: Green Chemistry and Sustainable Development Solutions, pp. 107-111, 2005.

[17] B. V. Rangan, D. Hardjito, S. E. Wallah, and D. M. J. Sumajouw, "Studies on fly ash-based geopolymer concrete," in Proceedings of the Geopolymer 2005 World Congress: Green Chemistry and Sustainable Development Solutions, pp. 133-137, 2005.

[18] D. Hardjito, S. E. Wallah, D. M. J. Sumjouw, and B. V. Rangan, "Effect of mixing time and rest period on the engineering of fly ash-based geopolymer concrete," in Proceedings of the Geopolymer 2005 World Congress: Green Chemistry and Sustainable Development Solutions, pp. 145-147, 2005.

[19] D. M. J. Sumajouw, D. Hardjito, S. E. Wallah, and B. V. Rangan, "Fly ash-based geopolymer concrete: an application for structural members," in Proceedings of the Geopolymer 2005 World Congress: Green Chemistry and Sustainable Development Solutions, pp. 149-152, 2005.

[20] V. F. F. Barbosa, K. J. D. MacKenzie, and C. Thaumaturgo, "Synthesis and characterisation of materials based on inorganic polymers of alumina and silica: sodium polysialate polymers," International Journal of Inorganic Materials, vol. 2, no. 4, pp. 309-317, 2000.

[21] J. G. S. van Jaarsveld, J. S. J. van Deventer, and G. C. Lukey, “The effect of composition and temperature on the properties of fly ash- and kaolinite-based geopolymers," Chemical Engineering Journal, vol. 89, no. 1-3, pp. 63-73, 2002.

[22] A. Palomo and A. Fernandez-Jimenez, "Alkaline activation of fly ashes: manufacture of concrete not containing Portland cement," in Proceedings of the International Conference in Institute Eduardo Torroja (CSIC '99), pp. 1-8, Madrid, Spain, 1999.

[23] R. V. Ranganath and S. Mohammed, "Some optimal values in geopolymer concrete incorporating fly ash," The Indian Concrete Journal, vol. 82, no. 10, pp. 26-34, 2008.

[24] B. M. Mustafa Al Bakri, H. Mohammed, H. Kamarudin, I. K. Niza, and Y. Zarina, "Review on fly ash based geopolymer concrete without Portland cement," Journal of Engineering and Technology Research, vol. 3, no. 1, pp. 1-4, 2011.

[25] S. S. Jamkar, Y. M. Ghugal, and S. V. Patankar, "Effect of fineness of fly ash on flow and compressive strength of geopolymer concrete," Indian Concrete Journal, vol. 87, no. 4, pp. 57-61, 2013.

[26] S. V. Patankar, S. S. Jamkar, and Y. M. Ghugal, "Effect of sodium hydroxide on flow and strength of fly ash based geopolymer mortar," Journal of Structural Engineering, vol. 39, no. 1, pp. 7-12, 2012. 

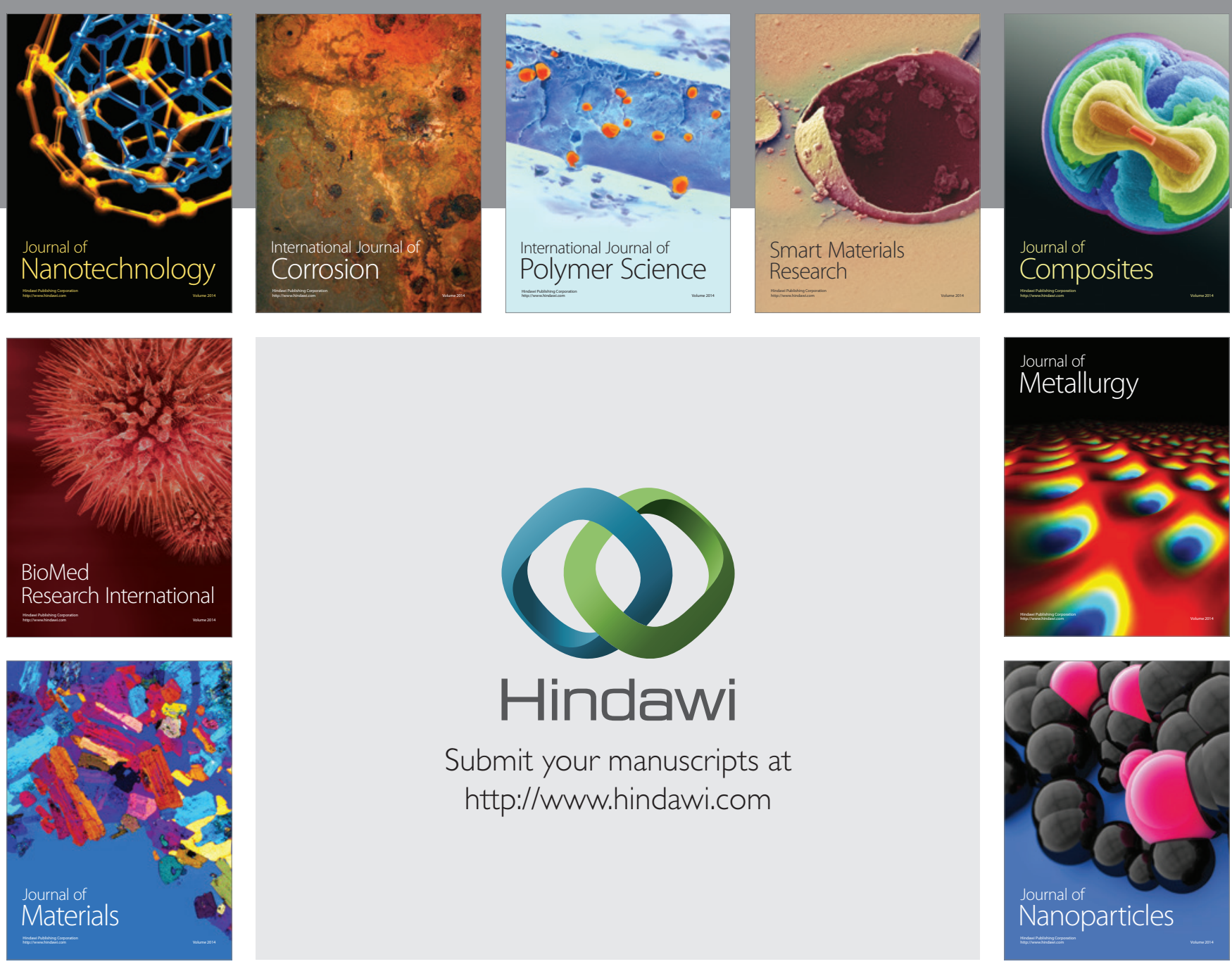

Submit your manuscripts at http://www.hindawi.com
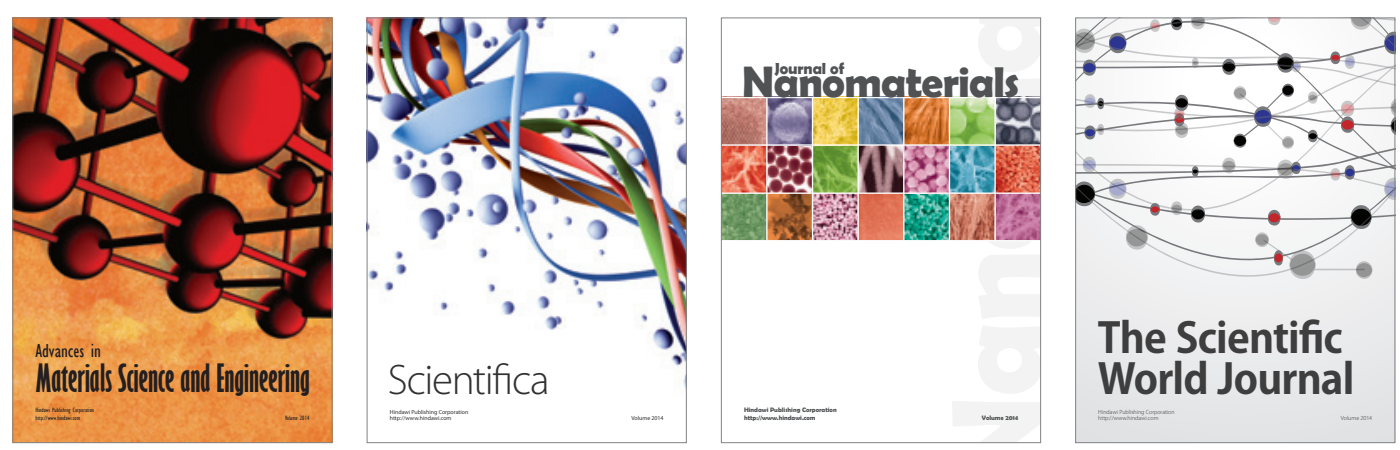

\section{The Scientific World Journal}
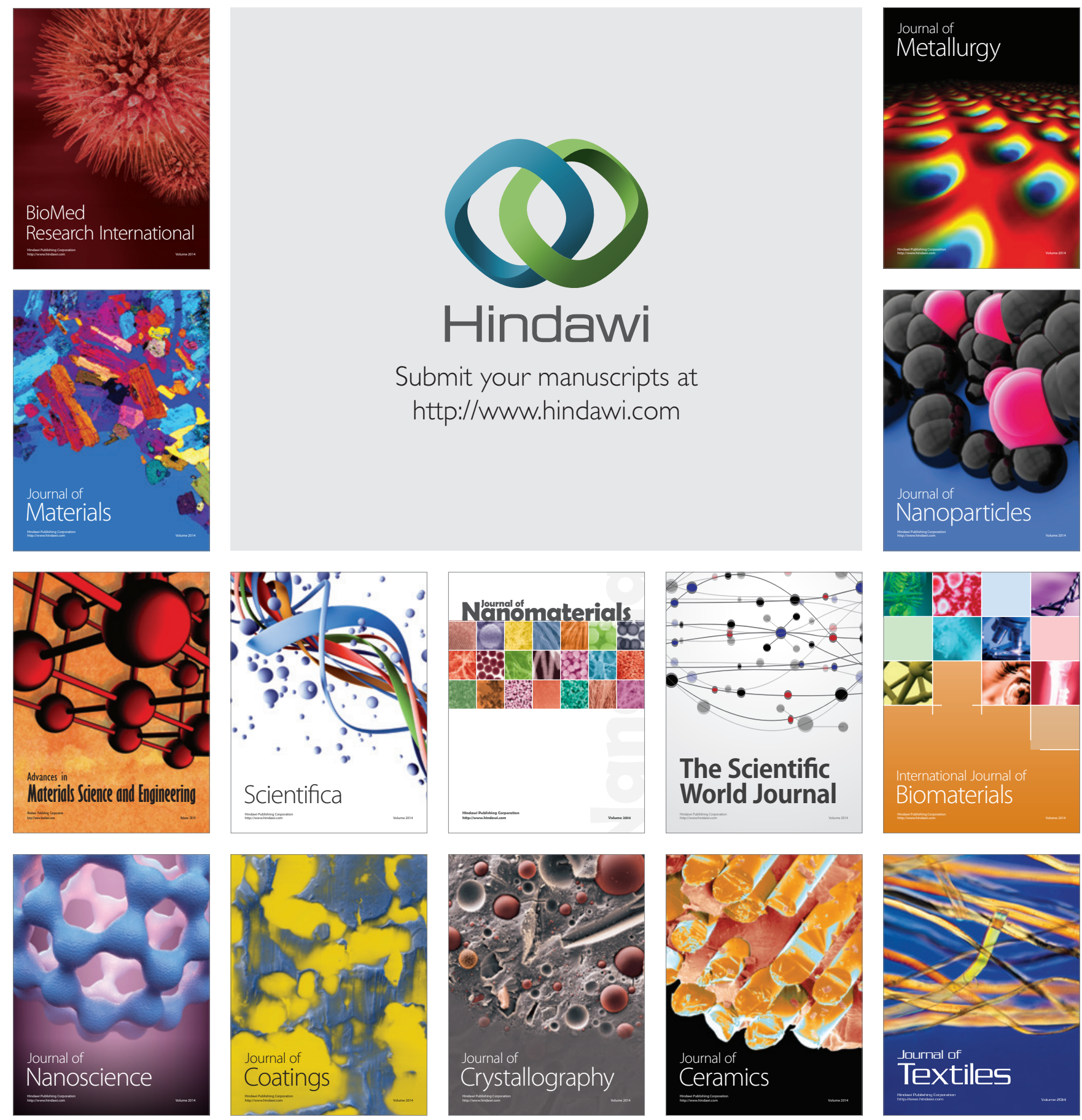